J. BASSAN, L. M. WILlis, R. N. VELLANKI, A. NGUYEN, L. J. EDGAR, B. G. WOUTERS, M. NITZ* (UNIVERSITY OF TORONTO AND UNIVERSITY HEALTH NETWORK, TORONTO, CANADA)

TePhe, A Tellurium-Containing Phenylalanine Mimic, Allows Monitoring of Protein Synthesis in Vivo with Mass Cytometry Proc. Natl. Acad. Sci. U. S. A. 2019, 116, 8155-8160.

\section{An in Vivo Mass Cytometry Probe for Protein Translation}
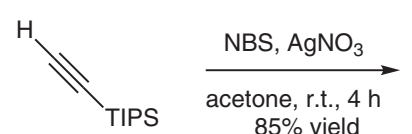

$85 \%$ yield
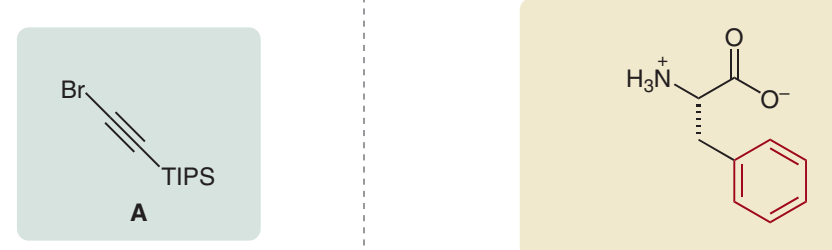

phenylalanine (Phe)<smiles>C#CC[C@H](NC(=O)O)C(=O)O</smiles>

$\mathrm{CuCl}, \mathrm{HONH}_{2} \cdot \mathrm{HCl}$ aq $\mathrm{BuNH}_{2}, \mathrm{O}^{\circ} \mathrm{C}, 5 \mathrm{~min}$

then $\mathbf{A}$

aq $\mathrm{BuNH}_{2}, 0^{\circ} \mathrm{C}, 30 \mathrm{~min}$ $88 \%$ yield

Cadiot-Chodkiewicz coupling<smiles>CC[NH2+]C#CC#CC[C@H](NC(=O)OCc1ccccc1)C(=O)[O-]</smiles>

1. TBAF

$$
\mathrm{THF}, 0^{\circ} \mathrm{C}, 1 \mathrm{~h}
$$

2. $\mathrm{NaBH}_{4}, \mathrm{Te}^{\mathrm{O}}$

$\mathrm{H}_{2} \mathrm{O}, 1 \mathrm{~h}$

then crude from 1 . in $\mathrm{EtOH}, 16 \mathrm{~h}$ $48 \%$ over 2 steps

\section{Key words}

mass cytometry

protein synthesis

tellurium

imaging mass

cytometry
Significance: Protein translation is a dynamic process that is challenging to monitor in vivo; however, competitive incorporation of unnatural amino acids is one way to introduce a probe for detection. Imaging mass cytometry (IMC) is an imaging technique that follows a similar workflow as immunofluorescence imaging. It uses a mass-tag instead of a fluorescent dye for detection and does not require post-translational modification. The geometric properties of tellurophene make the unnatural amino acid TePhe an excellent isostere of phenylalanine.
Comment: TePhe is a non-toxic small-molecule probe that can be used to measure and visualize protein translation both in vitro and in vivo. Exploiting the native translation machinery, TePhe is competitively incorporated into proteins without the need for phenylalanine starvation. Using IMC, protein synthesis in mice (gut, brain and tumor) was monitored with spatiotemporal precision. Tellurium isotope enrichment enables multi-channel observations. Additionally, this tellurium-containing probe has also high potential for use in NMR spectroscopy or X-ray crystallography. 